\title{
The importance of preserving the freshness of fish to fulfil the tayyiban based on the analysis of scientific and Islamic jurisprudence principles
}

\author{
1,* Kartika, B., ${ }^{1}$ Parson, S.W., ${ }^{1}$ Jamaludin, M.A., ${ }^{2}$ Husman, N.F. and ${ }^{1}$ Elgharbawy, A.A.M. \\ ${ }^{1}$ International Institute for Halal Research and Training, Level 3, KICT Building, International Islamic \\ University Malaysia (IIUM), PO Box 10, 50728 Kuala Lumpur \\ ${ }^{2}$ Kulliyyah of Islamic Revealed Knowledge and Human Sciences, Dept Fiqh and Usul Fiqh, International \\ Islamic University Malaysia (IIUM), PO Box 10, 50728 Kuala Lumpur
}

\author{
Article history: \\ Received: 27 August 2019 \\ Received in revised form: 31 \\ January 2020 \\ Accepted: 21 February 2020 \\ Available Online: 26 \\ February 2020
}

Keywords:

Perishability,

Fish,

Spoilage,

Halalan Tayyiban,

Qawaid Fiqhiyyah

(Principles of Islamic

Jurisprudence)

DOI:

https://doi.org/10.26656/fr.2017.4(S1).S24

\begin{abstract}
Perishability of fresh fish has become one major concern for both fish industry players as well as the consumers. If it is not properly handled and preserved, fish will be deteriorated and will lose its quality attributes. This is the point where the halalan tayyiban (lawful and wholesome) status of fish is depreciated and at the same time it affects the consumer purchase intention. This article discussed the perishability of fish, phenomenon of fish spoilage and its phases and methods which can be used to detect the deterioration. In addition, Islamic perspective on the importance of preserving the food safety, quality and halalan tayyiban status of raw fish or fish product along the processing line until reaching the consumer is also discussed according to the Maqasid al Shariah (The Objectives of Shari'ah) by using Qawaid Fiqhiyyah (Principles of Islamic Jurisprudence). The method used is the library research which includes the observation from Islamic perspectives. This is in line with achieving the highest objectives of Shariah, which is to protect the farmers, the environment, the aquaculture and the consumers. The output of the study may serve MyGAP and MS 1500:2009.
\end{abstract}

\section{Introduction}

Food sector or industry is tied with the issues related to food safety and quality, as well as the halalan tayyiban status of the food product especially among the Muslim consumers. According to Australian Institute of Food Safety (2019), food safety refers to the procedure or process involved in the production of food product such as handling, preparing and storing in a way that is free from the risk or factor that can lead to the occurrence of foodborne illness. Food quality, on the other hand, can be defined as the sum of all characteristics and measurable attributes of food in which usually can be determined based on three categories of quality, namely sensory value, suitability value and health value (Leitzmann, 1993). Quality can be in the form of positive and negative attributes and it affects the acceptance of consumer towards the value of the particular food product (WHO, 2017). The examples of positive attributes are colour, texture, flavor, origin and processing technique that involved in the production of food product, whereas negative attributes can be in the form of visible deterioration, contamination with something filthy, bad odors, bad taste and discoloration.
As for Halal term, Jabatan Kemajuan Islam Malaysia (JAKIM) (2015) states that it comes from Arabic word halla, yahillu, hillan, wahalalan which means lawful or permissible by the Shariah law, whereas tayyiban or tayyib means good, pure and wholesome (Abdullah, 2018). The halalan tayyiban concept must come in a package due to the fact that some food may be certified halal, which means it is free from prohibited substances according to Shariah law, but it may not be good (tayyib) to be consumed (Arif and Ahmad, 2011; Abdullah, 2018). For instance, junk food products that comply with the requirements for halal certification are certified as halal without doubt. However, the habit of eating junk food is considered unhealthy and could lead to many health problems over long period of time. Therefore, in the Shariah view's perspective, halalan tayyiban food should not contain any part or element that comes from the prohibited animal, such as pig and dog or animal that has not been slaughtered according to the Shariah law. Other than that, halalan tayyiban food must be free from najs or impure, any parts of the human body or its yield and hazardous or poisonous substances that can cause detrimental to human health.

Based on the definitions above, it is undeniable that 
those three elements are most crucial and must be seriously taken care of by food industry players. Ignorance of these elements can cause bad consequences to not only the entrepreneurs but also to the consumers. Customer who is affected will suffer foodborne illness symptoms, such as diarrhea, vomiting, nausea, fever, abdominal pain, loss of appetite and the worst is even death in some serious cases (FDA, 2018). Apart from that, based on Islamic point of view, consuming halalan tayyiban food is a devotion to Allah and will be rewarded and blessed by Him (Arif and Ahmad, 2011).

Aquaculture sector for the food fish rearing is considered as one of the branches in the food industry. Fishes that are reared through aquaculture system required proper care in terms of feeding and water environment as stated by Mahat (2019). However, fish requires other kinds of treatments during the post-harvest process due to its perishable nature or fast deteriorate after death. Due to its perishability, aquaculture product, such as freshwater fish must be treated accordingly prior to being sold to the consumer in order to ensure that customer received the highest quality, wholesome and halalan tayyiban raw fish or fish product. This article discusses the perishability of fish, the phenomenon of fish spoilage and its phases and methods than can be used to detect the deterioration. In addition, the Islamic perspective on the importance of preserving the food safety, quality and halalan tayyiban status of raw fish or fish product along the processing line until reaching the consumer is explained according to the Maqasid al Shariah by using Qawaid Fiqqiyyah (Principles of Islamic Jurisprudence). Finally, this article elaborates the concept of halal supply chain and its role in preserving consumer rights.

\section{Fish as perishable raw material}

Freshwater fish is one of highly perishable commodity due to its biological component, one of them is high in water content ranging between $65 \%$ and $80 \%$ (Steffens, 2006). Starting from the moment the fish is harvested from the pond, undergone processes until being ready to be consumed, temperature and methods of handling are two critical points that must be strictly controlled to preserve the fish quality and prevent it from spoilage. Apart from that, guidelines focusing on quality assurance must involve every phase in the processing line, such as transport and storage, as well as depuration of the fish.

It is recommended in freshwater fish processing to keep the fish alive as long as possible because it is rapidly susceptible to many forms of degradation after death, for instance in terms of flavor and texture. As precautions, dead fish should be beheaded, gutted, washed and chilled in order to minimize or stop microbiological processes and unfavorable enzymatic reaction from taking place. Besides that, fish has the potential to be contaminated due to temperature abuse during transportation and storage or contamination by food handlers or through cross-contamination caused by poor handling practice (Chintagari et al., 2016). Therefore, it is important to ensure the temperature throughout the processing line must be as low as possible. For example, at the harvest stage, fish must be chilled at $0^{\circ} \mathrm{C}$ in ice. From that point onwards, the ideal temperature to maintain the shelf life for any kind of fresh fish must be kept between $-1^{\circ} \mathrm{C}$ to $1^{\circ} \mathrm{C}$, whereas for frozen products, the ideal temperature is under $-23^{\circ} \mathrm{C}$ to ensure the products are well preserved (Morgan Cargo, 2019).

\section{Fish spoilage}

Fresh fish is easily deteriorated after being harvested if not treated accordingly. The spoilage process (rigor mortis) will start within 12 hours of their catch in the high ambient temperatures' region (Berkel et al., 2004). Rigor mortis is basically the process in which fish loses its flexibility due to stiffening of fish muscles after a few hours of its death (Adebowale et al., 2008). Most fish species degrade as a result of digestive enzymes and lipases, microbial spoilage from surface bacteria and oxidation (AMEC, 2003). During fish spoilage, there is a breakdown of various components and the formation of new compounds. These new compounds are responsible for the changes in odour, flavor and texture of the fish meat. This represents a major concern of the freshness of saleable products and the breakdown of proteins and lipids. Compositional changes during fish spoilage result in lipid oxidation and protein degradation as well as the loss of other valuable molecules.

\subsection{Mechanism of fish spoilage}

Mechanism of fish spoilage can be divided into three phases; autolytic enzymatic spoilage, oxidative spoilage and microbial spoilage.

\subsubsection{Autolytic enzymatic spoilage}

Soon after post-harvest, dead fish will undergo biological and chemical changes due to the enzymatic breakdown process of major fish molecules (FAO, 2005). Autolytic enzymes resulted in lowering the textural quality of fish in the beginning phase of deterioration yet will not cause spoilage characteristics such as off-odors and off-flavors (Hansen et al., 1996). This shows that the product quality of fish, as well as its shelf-life, can be limited by the autolytic degradation 
even if the presence of spoilage organisms relatively small. At this phase, textural quality is the most impacted characteristic together with the production of hypoxanthine and formaldehyde. The action of digestive enzymes leads to the extensive autolysis, given by the signs of meat softening, burst of the belly wall and drain out of the blood water which contains both protein and oil (FAO, 1986).

Several proteolytic enzymes that contribute to post mortem degradation in fish muscle and fish products during storage and processing are found in muscle and viscera of the post-harvest fish. The proteases have optimal $\mathrm{pH}$ in the alkaline to neutral range and the rate of degradation process caused by proteolytic enzymes action decrease when the fish was kept at $0^{\circ} \mathrm{C}$ and a $\mathrm{pH}$ of 5 (Martinez and Gildberg, 1988). Proteolysis which is responsible for the degradation of proteins will take place during improper storage of whole fish, subsequently followed by a process of solubilization (Lin and Park, 1996). Peptides and free amino acids produced as a result of autolysis of fish muscle proteins cause the spoilage in fish as the result of microbial growth and production of biogenic amines (Fraser and Sumar, 1998). The phenomenon of belly bursting in fish normally caused by leakage of proteolytic enzymes from pyloric caeca and intestine to the ventral muscle.

\subsubsection{Oxidative spoilage}

Fish that contains fat as one of its components is susceptible to the lipid oxidation. This process involves three stages free radical mechanism, namely initiation, propagation and termination (Frankel, 1985). Initiation is the first stage where lipid free radicals formed with the assist of catalyst such as heat, metal ions and irradiation. The free radicals formed then react with oxygen to form peroxyl radicals. In the propagation stage, the peroxyl radicals react with other lipid molecules to form hydroperoxides and a new free radical (Hultin, 1994). Lastly, termination occurs when these free radicals combine and interact to form nonradical products.

Oxidation occurs when oxygen reacts with the double bonds in fatty acids chain, thus fish that contain polyunsaturated fatty acids are highly susceptible to oxidation. Molecular oxygen needs to be activated in order to initiate the oxidation process and transition metals are the primary activators (Hultin, 1994). In fish, lipid oxidation can occur both enzymatically or nonenzymatically. The enzymatic hydrolysis of fats by lipases that can be found in skin, blood and tissue or termed as lipolysis (fat deterioration) split the glycerides, thus forming free fatty acids which are responsible for common off-flavour (rancidity) and reducing the oil quality. The main enzymes involved in fish lipid hydrolysis are triacyl lipase, phospholipase A2 and phospholipase B (Ghaly et al., 2010).

Non-enzymatic oxidation is caused by hematin compounds (hemoglobin, myoglobin and cytochrome) catalysis producing hydroperoxides (Fraser and Sumar, 1998). The formation of fatty acids as the product of hydrolysis of fish lipids interact with sarcoplasmic and myofibrillar proteins causing denaturation. Lipid oxidation can occur in fish muscle due to the highly prooxidative hemoglobin $(\mathrm{Hb})$, especially in the form of deoxygenated and/or oxidized. Lowering the $\mathrm{pH}$ by addition of acids can accelerate lipid oxidation through deoxygenated $\mathrm{Hb}$ (Undeland et al., 2005).

\subsubsection{Microbiological spoilage}

Basically, the composition of the microflora on postharvest fish depends on the microbial contents of the water in the habitat where they live. Based on Gram and Huss (2000), fish microflora includes bacterial species such as Pseudomonas, Alcaligenes, Vibrio, Serratia and Micrococcus. The major cause of fish spoilage is the production of amines, biogenic amines such as putrescine, histamine and cadaverine, organic acids, sulphides, alcohols, aldehydes and ketones with unpleasant and unacceptable off-flavors as the product from microbial growth and metabolism (Dalgaard et al., 2006).

For unpreserved fish, spoilage is a result of Gramnegative, fermentative bacteria (such as Vibrionaceae), whereas psychrotolerant Gram-negative bacteria (such as Pseudomonas spp. and Shewanella spp.) tend to spoil chilled fish (Gram and Huss, 2000). Trimethylamine (TMA) levels are used universally to determine microbial deterioration leading to fish spoilage. Fish use trimethylamine oxide (TMAO) as an osmoregulant to avoid tissue waterlogging in freshwater. Bacteria such as Shewanella putrifaciens, Aeromonas spp., psychrotolerant Enterobacteriaceae, P. phosphoreum and Vibrio spp. can obtain energy by reducing TMAO to TMA creating the ammonia-like off-flavors (Gram and Dalgaard, 2002).

\section{Maqasid al Shariah and Qawaid Fiqhiyyah in handling the freshness of fish}

Since fish is easily prone to deterioration, the fish industry player should take responsibility in ensuring and maintaining the fish quality by adherence to the established and reliable quality system. As for small scale fish industry that does not have the established system such as fishermen or wholesalers who sell their fish in the wet market, their integrity is required to ensure that the consumer gets only the best quality of 
fish. Some fish spoilage could be visible and easily detected, thus, can be directly rejected by the consumer. However, there was a case happened in Tawau, Sabah, whereby the raw fish seller cheated the buyers by selling deteriorated fishes. The tactic used was that they were using fresh fishes only for displaying purpose, but to put in the customer's basket, they would take the spoilt ones (Anuar and Sanudin, 2018).

As a Muslim, it is an obligation to give emphasis on the halalan tayyiban food for daily consumption. This is in line with what Allah commands in the Qur'an which means: "O mankind, eat from whatever is on earth (that is) lawful and good and do not follow the footsteps of Satan. Indeed, he is to you a clear enemy" (Surah Al Baqarah, 2:168). In this verse, it is clearly stated that human is commanded to eat only food that is halal (lawful) and tayyib (good, pure and wholesome). Consuming deteriorated or spoiled food exposes consumers to the risk of getting various diseases.

Ensuring the halalan tayyiban status of the food is only the right way consumers guarantee that the food product is in good condition, wholesome, and safe. There is a narration in the Hadith: On the authority of $\mathrm{Abu}$

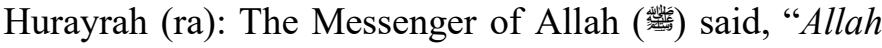
the Almighty is Good and accepts only that which is good. And verily Allah has commanded the believers to do that which He has commanded the Messengers. So the Almighty has said: "O (you) Messengers! Eat of the tayyibat [all kinds of halal (legal) foods], and perform righteous deeds." [23:51] and the Almighty has said: "O you who believe! Eat of the lawful things that We have provided you." [2:172]" Then he (wentioned [the case] of a man who, having journeyed far, is disheveled and dusty, and who spreads out his hands to the sky saying "O Lord! O Lord!," while his food is haram (unlawful), his drink is haram, his clothing is haram, and he has been nourished with haram, so how can [his supplication] be answered?"

There is no command or prohibition in the Islamic regulations except that its aim is to protect the welfare of mankind in line with Maqasid al-Shariah. In the Arabic language, maqasid is plural form from maqsad qasad, yaqsud, qasdan and maqsadan. Al-qasd from the point of language has multiple meanings. Among them, aspire (al -i'tizam), holding (al-i'timad), willfully (al-Amd), ask for something and bring something.

In general, Maqasid al-Shariah is intended to keep maslahah (well-being) and prevent from mafsadah (harm). Maslahah can only be achieved by keeping the most valuable thing in the life of human being, namely the five principles of Shariah (al-daruriyyat al-khams) (Al-Buti, 2005). The main five values that have been highlighted by the scholars are the protection of religion, life, intellect, lineage, and property. It is obligatory to protect all these five aspects. One way to protect religion is to do what Allah has ordained and refrain from what $\mathrm{He}$ has prohibited. Religion is the foundation. In fact, most scholars placed the protection of religion in the first category among the five fundamentals values (Dharuriyyat al Khams).

Shariah has set the obligations to act fairly and justly in all circumstances as Allah has decreed:

"We have already sent Our messengers with clear evidence and sent down with them the Scripture and the balance that the people may maintain [their affairs] in justice". (57:25).

This includes the just actions in business transaction among the people. Muamalah (lit. transactions) in Islam has a wide scope because the basic principle is all contracts and transactions are permissible unless there is evidence states that it is prohibited. Business transactions become unlawful due to various factors; unlawful due to its very essence (lizatihi), or due to oppression or deception (gharar) or due to usury (riba') or element of gambling in the business transaction. Allah said: "O you who have believed, do not consume one another's wealth unjustly but only [in lawful] business by mutual consent. And do not kill yourselves [or one another]. Indeed, Allah is to you ever Merciful".

If we look at the issue mentioned earlier, i.e. selling stale food, is against the rules laid down by Islam in Fiqh Mu'amalah whereby all food sold must be in good condition. The sellers are considered cheating if they know that the fish being sold are rotten and they continue selling it to the consumers. The Prophet forbids us from making the transaction which has the element of cheating. It was narrated in a Hadith:

"Whosoever wage war against us is not from amongst us and whosoever lied to us is not from amongst $u s "$

The Fuqaha' (scholars well-versed in Fiqh) reached a consensus that the phrase 'not from amongst us' is not to be taken literally to mean that he becomes an apostate rather it means it is not the way of a Muslim to cheat. (Tuhfah al-Ahwazi, 4/544). Therefore, it is clear that Islam forbids any form of cheating including in business transaction. Generally, business transactions that are forbidden according to Islamic regulations are due to elements of oppression that can lead to hostilities among mankind. This is what the satan hopes for as mentioned in the verse of Allah:

"And say to My servants that they should always 
speak (even when disputing with others) that which is the best. Satan is ever ready to sow discord among them. For Satan indeed is a manifest enemy to humankind."

It is true that fish is a kind of dead meat that is lawful to eat as being narrated in a hadith:

It was narrated from 'Abdullah bin 'Umar that the Messenger of Allah (waid: "Two kinds of dead meat and two kinds of blood have been permitted to us. The two kinds of dead meat are fish and locusts, and the two kinds of blood are the liver and spleen."(Sunan Ibn Majah, Vol 4, Book 29, Hadith number 3314)

But the issue here is, rotten or spoiled fish are filthy and harmful. Narrated by Abu Saíd al Khudary that the Prophet (the imposition of harm". (al Sunan al Kubra Hadith number 11070)

Apart from protecting religion, Shariah also protects life, intellect, lineage, and property. Eating healthy and nutritious food is also a form of protecting life and intellect. It makes the body fit and it impacts on the function of the mind. There is an Arabic proverb " $a$ sound mind is in a sound body". It is the mind that distinguishes man from other creations, and it is the main reason for a person to be held accountable to fulfil and act according to Allah's commands. Therefore, it is essential for a person to avoid spoiled food that will lead to harmful consequences.

Among the method of Islamic Jurisprudence (Fiqh) used in this aspect is "avoiding detriment takes precedence over bringing about benefit". This method stresses that to avoid harm is more important than to derive benefit because the Islamic regulation puts more emphasis avoiding the unlawful from those which are permissible. The basic principle is whatever is harmful is prohibited. Allah states in Qurán,

"... and make not your own hands contribute to (your) destruction, but do good; for Allah loves those who do good." (Surah al Baqarah, 2:195)

Based on the discussion on Islamic perspective derived from the Qur'an, Hadith and edicts of the Fiqh, it can be concluded that any action which leads to destruction and harm, like cheating in dealing business is forbidden and the authorities should come up with solution to stop the irresponsible seller from selling spoiled fish which can cause bad health effect to the consumers.

\section{Importance of halal supply chain to preserve consumer's rights}

The halal supply chain is a system that applies the principle of halalan tayyiban compliance with the Islamic law throughout the supply chain starting from the sources of supply until reaching the consumers (Adura Mohd Yusoff et al., 2015). The processes involved include warehousing, sourcing, transportation, handling of products, inventory management, procurement and order management which must comply with the Shariah law (Omar and Jaafar, 2011). Along with these processes, there are many chances that food product being exposed to the risk of non-halal ingredients as well as hazards that could be in the form of biological, chemical or physical and eventually changing the halalan tayyiban status of the products.

In Islamic teaching, fish is one of the dead meat that is permissible to be consumed without conducting Islamic ritual slaughtering. However, it should be emphasized here that the state of the fish is important when it comes to determining the halalan tayyiban status of the fish. Newly post-harvest and fresh fish that is reared in Shariah compliance pond system is definitely halal and safe for consumption. On the other hand, if the fish is newly caught and fresh but reared in the pond that does not adhere with Shariah compliance, for instance using filthy sources for feeding, the halalan tayyiban specification will not be achieved.

As to preserve the consumers' right, halal supply chain is seen to be promising. According to study conducted by Adura Mohd Yusoff et al. (2015) about the relationship between each of the components of halal food supply chain knowledge and purchase intention, for the slaughtered animals, it shows that knowledge about halal slaughtering, handling and storage, and packaging is the best indicator of consumers' purchase intention for halal food. As for the practices in aquaculture which does not involve slaughtering, the consumers are still emphasized to know the status of the products they receive, to ensure that their rights are preserved in terms of the safety and the wholesomeness of their consumption.

\section{Conclusion}

The paper has reviewed some Quranic verses and Islamic values from Jurists that are highly associated with the implementation of good aquaculture practices. Some aquaculture practices are far from ideal as humans are naturally greedy and they only care about profitability. From the scientific point of view, spoilage in fish can occur rapidly due to the perishability natures of fish itself. Proper handling and preservation are 
required to ensure the fish are kept fresh and nutritious. This is to ensure that the tayyiban value is prioritized and the products can be consumed without a doubt. Thus the objectives of Shariah, which include the protection of life is achieved.

\section{Acknowledgment}

The authors are thankful to the Ministry of Education of Malaysia for the funding through FRGS FRGS/1/2018/SSI03/UIAM/02/3 grant.

\section{References}

Abdullah, A. (2018). Difference between Halal and Halalan-Toyyiban. Retrieved July 18, 2019, from New Straits Times website: https:// www.nst.com.my/opinion/ columnists/2018/04/357046/difference-betweenhalal-and-halalan-toyyiban

Adebowale, B.A., Dongo, L.N., Jayeola, C.O. and Orisajo, S.B. (2008). Comparative quality assessment of fish (Clarias gariepnius) smoked with cocoa pod husk and three other different smoking materials. Journal of Food Technology, 6(1), 5-8.

Adura Mohd Yusoff, F., Nerina Raja Yusof, R. and Rahayu Hussin, S. (2015). Halal Food Supply Chain Knowledge and Purchase Intention. International Journal of Economics and Management, 9(S), 155172.

AMEC. (2003). Management of wastes from Atlantic seafood processing operations. Dartmouth, Nova Scotia, Canada: AMEC Earth and Environmental Limited.

Anuar, A. and Sanudin, H. (2018). KPDNHEP Sudah Turun Padang Siasat Isu Tular Ikan Busuk. Utusan Borneo.

Arif, S. and Ahmad, R. (2011). Food quality standards in developing quality human capital: An Islamic perspective. African Journal of Business Management, 5(31), 12242-12248. https:// doi.org/10.5897/AJBM10.1692

Australian Institute of Food Safety. (2019). What is Food Safety? Retrieved July 18, 2019 from Australian Institute of Food Safety: https:// www.foodsafety.com.au/resources/articles/what-isfood-safety

Berkel, B.M., Boogaard, B.V. and Heijnen, C. (2004): Preservation of Fish and Meat., p. 78-80. Wageningen, The Netherlands: Agromisa Foundation.

Chintagari, S., Hazard, N., Edwards, G., Jadeja, R. and Janes, M. (2016). Risk Associated with Fish and
Seafood. In Thakur, S. and Kniel, K.E. (Ed.) Preharvest Food Safety, p. 123-142. United States: American Society for Microbiology. https:// doi.org/10.5897/AJBM10.1692

Dalgaard, P., Madsen, H.L., Samieian, N. and Emborg, J. (2006). Biogenic amine formation and microbial spoilage in chilled garfish (Belone belone) effect of modified atmosphere packaging and previous frozen storage. Journal of Applied Microbiology, 101(1), 80 $-95$. https://doi.org/10.1111/j.13652672.2006.02905.x

FAO. (1986). Fisheries Technical Papers-T142. The production of fish meal and oil. Rome, Italy: Fisheries Industries Division, Food and Agriculture Organization of the United Nations.

FAO. (2005). Post-harvest changes in fish. Rome, Italy: FAO Fisheries and Aquaculture Department, Food and Agriculture Organization.

FDA. (2018). What You Need to Know about Foodborne Illnesses. Retrieved July 18, 2019 from FDA website: https://www.fda.gov/food/consumers/whatyou-need-know-about-foodborne-illnesses

Frankel, E.N. (1985). Chemistry of free radical and singlet oxidation of lipids. Progress in Lipid Research, 23(4), 197-221. https:// doi.org/10.1016/0163-7827(84)90011-0

Fraser, O. and Sumar, S. (1998). Compositional changes and spoilage in fish. Nutrition and Food Science, 98, 275-279.

https:// doi.org/10.1108/00346659810224208

Ghaly, A.E., Dave, D., Budge, S. and Brooks, M.S. (2010). Fish Spoilage Mechanisms and Preservation Techniques: Review. American Journal of Applied Sciences, 7(7), 859-877. https://doi.org/10.3844/ ajassp.2010.859.877

Gram, L. and Dalgaard, P. (2002). Fish spoilage bacteria problems and solutions. Current Opinion Biotechnology, 13(3), 262-266. https:// doi.org/10.1016/S0958-1669(02)00309-9

Gram, L. and Huss, H.H. (2000). Fresh and Processed Fish and Shellfish. In Lund, B.M., Baird Parker, A.C. and Gould G.W. (Eds.) The Microbiological Safety and Quality of Foods., p. 472-506. London: Chapman and Hall.

Hansen, T.L., Gill, T., Rontved S.D. and Huss, H.H. (1996). Importance of autolysis and microbiological activity on quality of cold-smoked salmon. Food Research International, 29(2), 181-186. https:// doi.org/10.1016/0963-9969(96)00003-8

Hultin, H.O. (1994). Oxidation of Lipids in Seafoods. In Shahidi, F. and Botta, J.R. (Eds.) Seafoods Chemistry, Processing Technology and Quality. 1st 
ed., p. 49-74. London, UK: Blackie Academic and Professional. https://doi.org/10.1007/978-1-46152181-5_5

Jabatan Kemajuan Islam Malaysia (JAKIM). (2015). Manual Procedure for Malaysia Halal Certificate $\left(3^{\text {rd }}\right.$ Revision) 2014. Serdang, Malaysia: Firdaus Press.

Jonsdottir, S. (1992). Quality index method and TQM system. In Olafsson, R. and Ingthorsson A.H. (Ed.) Quality issues in the fish industry. Proceedings from the COMETT conference course: quality issues in the fish industry, European cooperation., p. 81-94. Reykjavik: The Research Liaison Office, University of Iceland

Leitzmann, C. (1993). Food Quality-Definition and a Holistic View. In Sommer, H., Peterson, B. and v. Wittke, P. (Eds.). Safeguarding Food Quality., p. 315. Berlin, Heidelberg: Springer Berlin Heidelberg. https://doi.org/10.1007/978-3-642-78025-7_2

Lin, T.M. and Park, J.W. (1996). Protein solubility in Pacific whiting affected by proteolysis during storage. Journal of Food Science, 61(3), 536-539. https://doi.org/10.1111/j.1365-2621.1996.tb13151.x

Mahat, F. (2019, February 10). Businesses Find It Difficult To Become Shariah-Compliant. Retrieved from Bernama.com website: http:// www.bernama.com/en/news.php?id=1696625

Martinez, A. and Gildberg, A. (1988). Autolytic degradation of belly tissue in anchovy (Engraulis encrasicholus). International Journal of Food Science Technology, 23(2), 185-194. https:// doi.org/10.1111/j.1365-2621.1988.tb00566.x

Morgan Cargo. (2019). Seafood and Fish. Retrieved July 20, 2019, from Morgan Cargo website: http:// www.morgancargo.com/industry-verticals/perishable -cargo/seafood-fish/

Omar, E.N. and Jaafar, H.S. (2011). Halal Supply Chain in the Food Industry- A conceptual Model presented at 2011 IEEE Symposium on Business, Engineering and Industrial Applications (ISBEIA), 25-28 September 2011. Langkawi, Malaysia: IEEE. https:// doi.org/10.1109/ISBEIA.2011.6088842

Steffens, W. (2006). Freshwater Fish-Wholesome Foodstuffs. Bulgarian Journal of Agricultural Science, 12, 320-328.

Undeland, I., Hall, G., Wendin, K., Gangby, I. and Rutgersson, A. (2005). Preventing lipid oxidation during recovery of functional proteins from herring (Clupea harengus) fillets by an acid solubilization process. Journal of Agriculture and Food Chemistry, 53, 5624-5634. https://doi.org/10.1021/jf0404445

WHO. (2017). World Health Organization, Food Safety: What you should know. Retrieved from SEARO,
WHO website: http://www.searo.who.int/entity/ world_health_day/2015/whd-what-you-shouldknow/en/ 